\title{
LKB1/AMPK pathway mediates resistin-induced cardiomyocyte hypertrophy in H9c2 embryonic rat cardiomyocytes
}

\author{
PENG LIU ${ }^{1}$, GUAN-CHANG CHENG ${ }^{2}$, QUN-HUI YE ${ }^{2}$, YONG-ZHI DENG ${ }^{1}$ and LIN WU $^{2}$ \\ ${ }^{1}$ Department of Cardiovascular Surgery, The Affiliated Cardiovascular Hospital of Shanxi Medical University, \\ and Shanxi Cardiovascular Hospital (Institute), Taiyuan, Shanxi 030024; ${ }^{2}$ Department of Cardiology, \\ Huaihe Hospital of Henan University, Kaifeng, Henan 475000, P.R. China
}

Received September 24, 2015; Accepted January 27, 2016

DOI: 10.3892/br.2016.593

\begin{abstract}
Resistin has been previously demonstrated to induce cardiac hypertrophy, however, the underlying molecular mechanisms of resistin-induced cardiac hypertrophy remain unclear. Using $\mathrm{H} 9 \mathrm{c} 2$ cells, the present study investigated the liver kinase B1 (LKB1)/adenosine monophosphate-activated protein kinase (AMPK) signaling pathway for a potential role in mediating resistin-induced cardiomyocyte hypertrophy. Treatment of $\mathrm{H} 9 \mathrm{c} 2$ cells with resistin increased cell surface area, protein synthesis, and expression of hypertrophic marker brain natriuretic peptide and $\beta$-myosin heavy chain. Treatment with metformine attenuated these effects of resistin. Furthermore, treatment with resistin decreased phosphorylation of LKB1 and AMPK, whereas pretreatment with metformin increased phosphorylation of LKB1 and AMPK that is reduced by resistin. These results suggest that resistin induces cardiac hypertrophy through the inactivation of the LKB1/AMPK cell signaling pathway.
\end{abstract}

\section{Introduction}

Cardiac hypertrophy is an adaptive response to stimulation to heart, eventually progressing to heart failure. Features of cardiac hypertrophy include increased cardiomyocyte size, protein synthesis, elevated fetal gene atrial natriuretic peptide (ANP), brain natriuretic peptide (BNP), $\beta$-myosin heavy chain $(\beta-\mathrm{MHC})$ and fibronectin protein expression, and abnormal sarcomeric organization. Cell signaling pathways involved

Correspondence to: Professor Yong-Zhi Deng, Department of Cardiovascular Surgery, The Affiliated Cardiovascular Hospital of Shanxi Medical University, and Shanxi Cardiovascular Hospital (Institute), Taiyuan, Shanxi 030024, P.R. China

E-mail: 13834591065@163.com

Professor Lin Wu, Department of Cardiology, Huaihe Hospital of Henan University, Kaifeng, Henan 475000, P.R. China

E-mail: linwu71ch@yahoo.com

Key words: resistin, cardiac hypertrophy, liver kinase B1, adenosine monophosphate-activated protein kinase, cell signaling pathway in cardiac hypertrophy include mitogen-activated protein kinase (MAPK), adenosine monophosphate-activated protein kinase (AMPK), transforming growth factor $\beta$ (TGF- $\beta$ )/smads, Ras/Rho, janus kinase (JAK)/signal transducers and activators of transcription (STAT), and calcinurin/nuclear factor of activated T-cells (NFAT) $(1,2)$.

LKB1 is a signaling protein $(3,4)$ that forms a complex with sterile-20-related adaptor (STRAD) and mouse protein-25 (MO25). STRAD and MO25 are required for the activity of LKB1 $(5,6)$. AMPK is a substrate of LKB1, and is composed of AMPK $\alpha, A M P K \beta$ and AMPK $\gamma$ subunits. AMPK $\alpha$ is a catalytic subunit, composed of AMPK $\alpha 1$ and AMPK $\alpha 2$. $\mathrm{AMPK} \beta$ and AMPK $\gamma$ are regulatory subunits. AMPK $\alpha 1$ is widely expressed, whereas AMPK $\alpha 2$ is primarily expressed in liver cells and skeletal and cardiac muscle (7). The LKB1/AMPK pathway mediates various biological functions, including proliferation, apoptosis, autophagy and transcription $(8,9)$.

Resistin is an adipocyte-secreted cytokine that is linked to obesity, diabetes, insulin resistance, and cardiac hypertrophy $(10,11)$. Treatment of wild-type mice with resistin causes glucose intolerance (12), and immunoneutralization of resistin in obese mice decreases insulin sensitivity (10). Resistin can be regulated by a number of cytokines, including endothelin (ET), insulin, insulin-like growth factors (IGFs), and peroxisome proliferator-activated receptor (PPAR). Furthermore, resistin has been reported to induce cardiac hypertrophy through a number of signaling pathways, such as extracellular signal-regulated kinases (ERK), AMPK/mammalian target of rapamycin (mTOR), and the c-Jun NH (2)-terminal kinase (JNK)/insulin receptor substrate 1 (IRS1) pathway $(11,13)$. The underlying molecular mechanisms by which resistin induces cardiac hypertrophy are still not completely understood.

The aim of the present study was to investigate the effects of resistin on LKB1/AMPK cell signaling and the induction of cardiac hypertrophy in the $\mathrm{H} 9 \mathrm{c} 2$ rat myoblast cell line.

\section{Materials and methods}

Reagents. Recombinant human resistin was purchased from PeproTech, Inc. (Rocky Hill, NJ, USA). Metformin was ordered from Sigma-Aldrich (St. Louis, MO, USA). The H9c2 rat cardiomyoblast cells were obtained from the American Type Culture Collection (Manassas, VA, USA). Fetal calf serum (FCS) was 
purchased from Zhejiang Tianhang Biological Technology (Zhejiang, China). Antibodies raised against phospho-LKB1, LKB, phospho-AMPK and AMPK were purchased from Cell Signaling Technology, Inc. (Danvers, MA, USA). The UNIQ-10 column TRIzol ${ }^{\circledR}$ kit was ordered from Sangon Biotech Co., Ltd. (Shanghai, China). PrimeScript ${ }^{\circledR}$ RT Master Mix Perfect Real Time and SYBR ${ }^{\circledR}$ Premix Ex Taq ${ }^{\mathrm{TM}}$ II were obtained from Takara (Tokyo, Japan).

H9c2 cell culture. $\mathrm{H} 9 \mathrm{c} 2$ rat cardiomyoblast cells were cultured in DMEM containing $10 \%$ FCS, $1 \%$ penicillin and $1 \%$ streptomycin at a temperature of $37^{\circ} \mathrm{C}$ with a $5 \% \mathrm{CO}_{2}$ atmosphere. Once cells had reached $70-80 \%$ confluence, they were passaged according to a $1: 2$ or 1:3 proportion. The medium was changed every 2 days. Cells were seeded at a density of $1 \times 10^{5}$ into a $35 \mathrm{~mm}$ tissue culture dish. Cells were cultured in serum-free medium overnight and treated with resistin at a concentration of $50 \mathrm{ng} / \mathrm{ml}$ for the indicated time.

Determination of cell surface area. In total, $8 \times 10^{4}$ cells were seeded in a $35-\mathrm{mm}$ dish. Cells were cultured with serum-free DMEM overnight and treated with resistin for $48 \mathrm{~h}$. The cell surface area was determined via quantification of the total surface (NIH Image J version 1.49 software, Bethesda, MD, USA). Five observation fields were selected at random and 10 cells in each observation field were selected for measurement of cell surface area (14).

Protein synthesis measurement. In total, $1 \times 10^{5}$ cells were seeded in a 35-mm dish. Cells were cultured with serum-free DMEM overnight and treated with resistin for $48 \mathrm{~h}$. Cells were digested with trypsin and counted under a microscope. The cells were then collected and lysed in $100 \mu \mathrm{l}$ of RIPA buffer. Protein concentrations were measured using the Bradford protein assay kit (Bio-Rad Laboratories, Inc., Hercules, CA, USA). Cell protein synthesis was determined by dividing the total amount of protein by the cell number (15). The trypan blue exclusion test of cell viability was used to determine the number of viable cells present in a cell suspension.

Reverse transcription-quantitative polymerase chain reaction $(R T-q P C R)$. Cells were collected and RNA was extracted using the UNIQ-10 column TRIzol kit (Shanghai Sangon Biotech) and treated with DNase. A total of $1 \mu \mathrm{g}$ of RNA was reverse transcribed to cDNA using the PrimeScript ${ }^{\circledR}$ RT Master Mix Perfect Real-Time Kit (Takara), according to the manufacturer's instructions. PCR amplification was conducted with SYBR ${ }^{\circledR}$ Premix Ex Taq ${ }^{\mathrm{TM}}$ II kit (Takara) using the Applied Biosystems ${ }^{\circledR} 7500$ Fast Real-Time PCR System (Thermo Fisher Scientific, Inc., Waltham, MA, USA). The PCR reaction conditions were: $95^{\circ} \mathrm{C}$ for $30 \mathrm{sec}$, then 40 cycles of $95^{\circ} \mathrm{C}$ for $5 \mathrm{sec}$ followed by $60^{\circ} \mathrm{C}$ for $31 \mathrm{sec}$. $18 \mathrm{~s}$ was used as a reference gene. The $\Delta \Delta \mathrm{Cq}$ method was used for relative quantification. The BNP, $\beta$-MHC and 18 s primers were designed and synthesized by Sangon Biotech Co., Ltd. The nucleotide sequences of the primers were as follows: BNP forward, 5'-GGAGCATTGAGTTGGCTCTC-3' and reverse, 5'-CCAGCTCTCCGAAGTGTTTC-3'; $\beta$-MHC forward, 5'-CACCCGCGAGTACAACCTTC-3' and reverse, 5'-CCC ATACCCACCATCACACC-3'; 18s forward, 5'-CACCCG
CGAGTACAACCTTC-3' and reverse, 5'-CCCATACCCACC ATCACACC-3'.

Western blot analysis. Once the cells has reached $80-90 \%$ confluence, they were washed twice with phosphate-buffered saline, digested with $0.05 \%$ trypsin (Beyotime Biotechnology, Beijing, China) for $1 \mathrm{~min}$ and centrifuged at $1,000 \mathrm{x} \mathrm{g}$ for $5 \mathrm{~min}$. Cells were mixed with $100 \mu \mathrm{l}$ of lysis buffer and incubated on ice for $20 \mathrm{~min}$. Lysates were centrifuged at $1,000 \mathrm{x} \mathrm{g}$ and protein concentration was measured using the bicinchoninic acid assay. 5X Laemmli's buffer was added to samples, which were then heated at $95^{\circ} \mathrm{C}$ for $5 \mathrm{~min}$ and then separated by $10 \%$ sodium dodecyl sulfate-polyacrylamide gel electrophoresis. The proteins were transferred onto polyvinylidene fluoride membranes (EMD Millipore, Billerica, MA, USA). The membranes were blocked with TBST buffer $(20 \mathrm{mM}$ Tris- $\mathrm{HCl}, 150 \mathrm{mM} \mathrm{NaCl}$ and $0.1 \%$ Tween-20) containing 5\% non-fat milk for $1 \mathrm{~h}$ at room temperature. The membranes were incubated in TBST buffer containing 5\% non-fat milk with the primary antibodies p-LKB1 (cat. no. 3482S; monoclonal rabbit anti-rat; 1:1,000; Cell Signaling Technology, Inc.), LKB1 (cat. no. 3047S, monoclonal rabbit anti-rat; 1:1,000; Cell Signaling Technology, Inc.), p-AMPK (cat. no. 2531S; polyclonal rabbit anti-rat; 1:1,000; Cell Signaling Technology, Inc.), AMPK (cat. no. 5831S; monoclonal rabbit anti-rat; 1:1,000, Cell Signaling Technology, Inc.), $\beta$-actin (cat. no. 4967S; polyclonal rabbit anti-rat; 1:1,000; Cell Signaling Technology, Inc.) at $4^{\circ} \mathrm{C}$ overnight. Following primary antibody incubation, the membranes were incubated with anti-rabbit secondary antibodies (cat. no. 111-035-003; polyclonal goatanti rabbit; 1:10,000; Jackson ImmunoResearch, Inc., West Grove, PA, USA) conjugated to horseradish peroxidase at room temperature for $1 \mathrm{~h}$. The protein bands were visualised using an enhanced chemiluminescence kit (ComWin Biotech, Beijing, China) and FluorChem ${ }^{\mathrm{TM}} \mathrm{Q}$ Quantitative Western Blot Imaging System (Bio-Techne, Minneapolis, MN, USA). The band intensities were measured with ImageJ software, and the ratio of phosphorylated protein antibodies over corresponding total protein antibodies was calculated.

Statistical analysis. All experiments data were expressed as means \pm SD and performed at least three times. The Student's $\mathrm{t}$-test was used for statistical analysis and the differences were considered statistically significant if $\mathrm{P}<0.05$.

\section{Results}

Resistin treatment increases $H 9 c 2$ cell size, which is reversed by metformin. Resistin treatment was used to induce cardiomyocyte hypertrophy. H9c2 cells were treated with resistin at $50 \mathrm{mg} / \mathrm{ml}$ for $48 \mathrm{~h}$. Resistin increased cell surface area significantly compared to the control group $(\mathrm{P}<0.01$; Fig. 1). Pre-treatment of cardiomyocytes with metformin led to a significantly decreased resistin-induced cell surface area $(\mathrm{P}<0.01$, Fig. 1).

Resistin increases the synthesis cardiomyocyte protein synthesis and opposes the effects of metformin treatment. To investigate whether resistin treatment increases protein synthesis in H9c2 cells and that this increase is inhibited by 


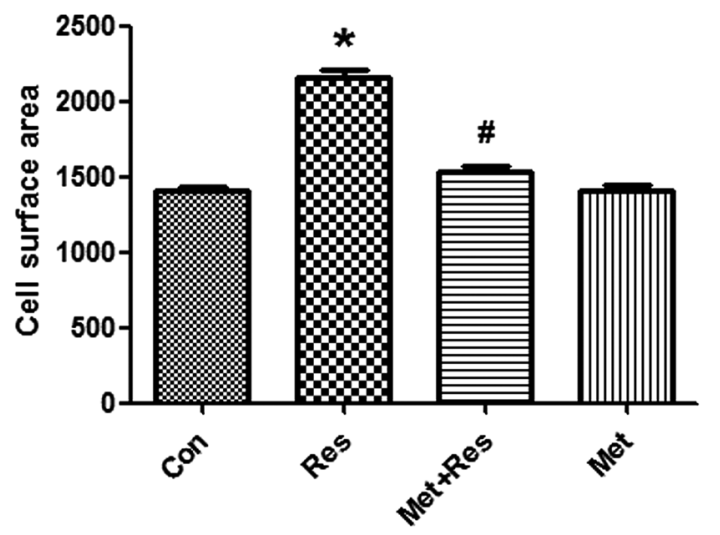

Figure 1. Resistin increases cell surface areas. Cell surface areas were measured using ImageJ software. Data represent the mean $\pm \mathrm{SD} .{ }^{*} \mathrm{P}<0.01$ vs. the control group, ${ }^{\#} \mathrm{P}<0.01$ vs. the resistin group. Con, control; Res, resistin Met+Res, metformin+resistin; Met, metformin.

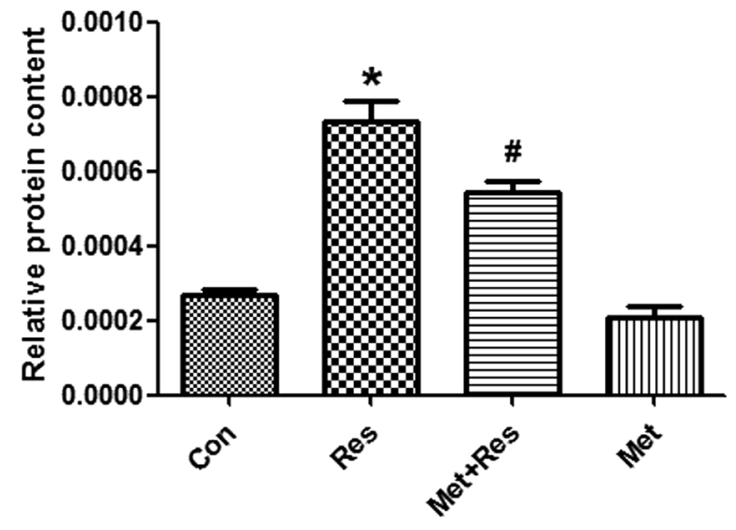

Figure 2. Resistin increases protein synthesis. Cell protein contents were measured and normalized to the cell number. Data represent the mean $\pm \mathrm{SD}$. ${ }^{\text {"P }}<0.01$ vs. the control group, ${ }^{\#} \mathrm{P}<0.05$ vs. the resistin group. Con, control; Res, resistin; Met+Res, metformin+resistin; Met, metformin.
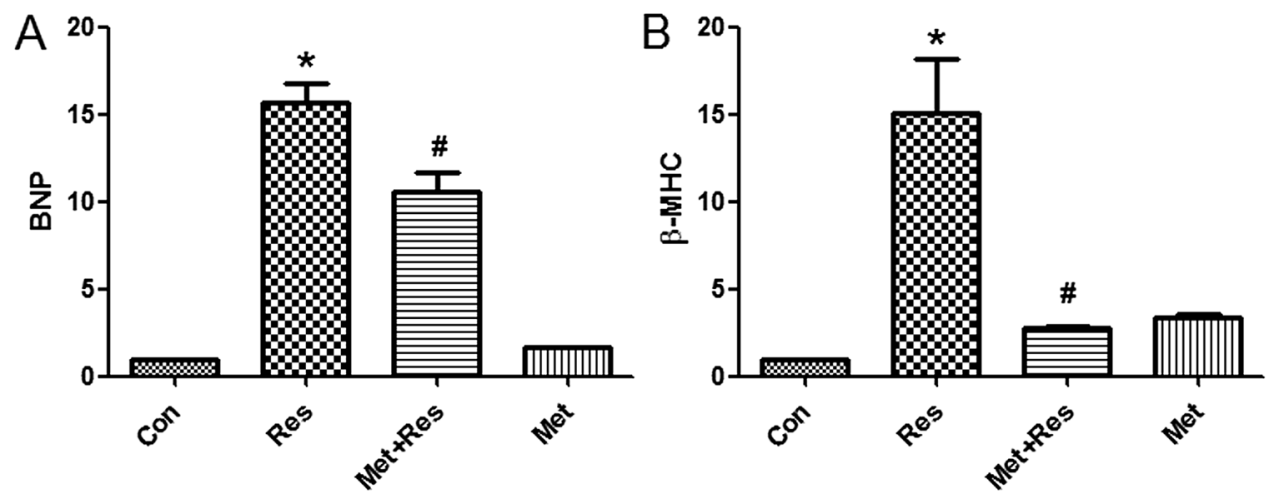

Figure 3. Resistin increases BNP and $\beta$-MHC mRNA expression that are reduced by metformin. (A) BNP mRNA and (B) $\beta$-MHC mRNA levels were examined by reverse transcription quantitative PCR. Data represent the mean $\pm \mathrm{SD}$. ${ }^{*} \mathrm{P}<0.01$ vs. the control group, ${ }^{*} \mathrm{P}<0.05$ vs. the resistin group. Con, control; Res, resistin; Met+Res, metformin+resistin; Met, metformin; BNP, brain natriuretic peptide; $\beta$-MHC, $\beta$-myosin heavy chain.
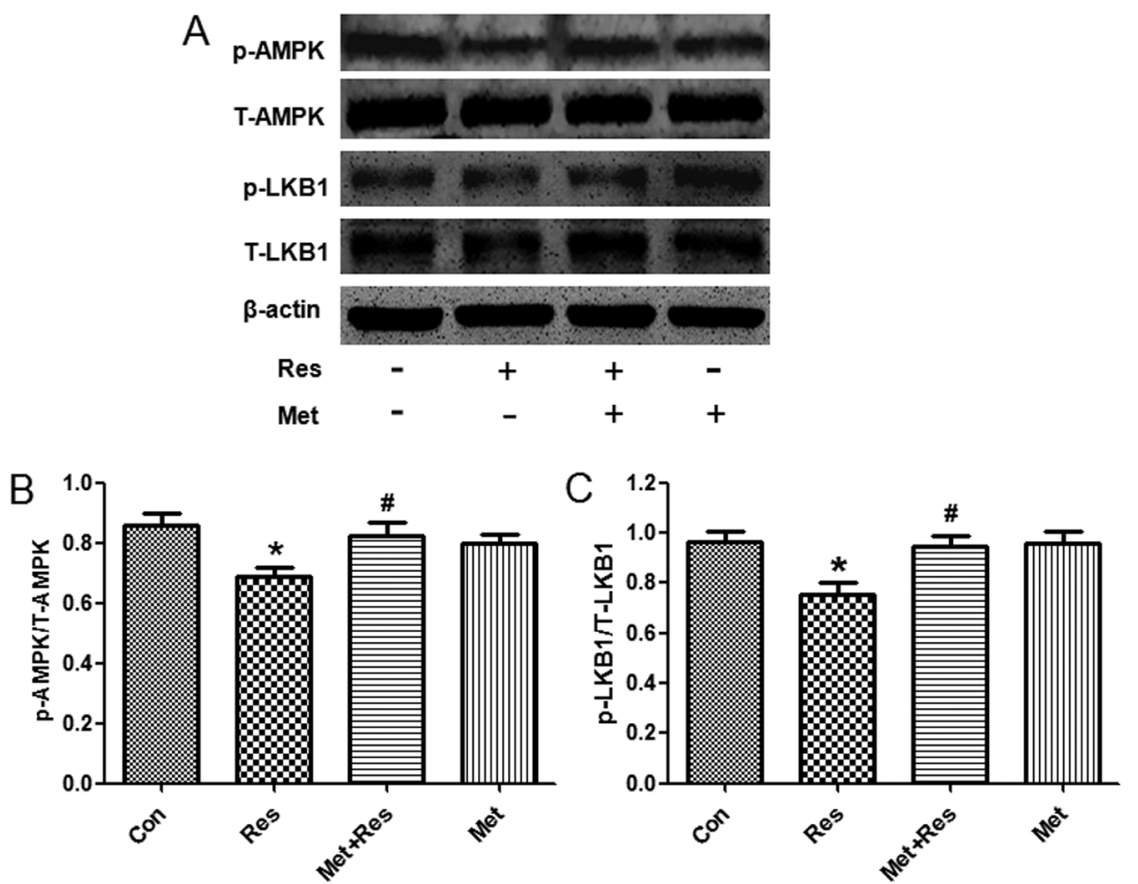

Figure 4. Resistin decreases phosphorylated liver kinase B1 (LKB1) and AMP-activated protein kinase (AMPK) expression. (A) Representive western blot. (B) The expression of p-AMPK normalized with AMPK. (C) The expression of p-LKB1 normalized with LKB1. Data represent the mean \pm SD. "P<0.05 vs. the control group, ${ }^{\text {}} \mathrm{P}<0.05$ vs. the resistin group. Con, control; Res, resistin; Met+Res, metformin+resistin; Met, metformin. 
metformin, cultured cardiomyocytes were exposed to resistin in the presence and/or absence of metformin for $48 \mathrm{~h}$. The results demonstrate that resistin significantly increased protein synthesis in cardiomyocyotes ( $\mathrm{P}<0.05$; Fig. 2). Furthermore, metformin treatment significantly decreased the synthesis of proteins that were increased by resistin $(\mathrm{P}<0.05$; Fig. 2$)$.

Resistin treatment elevates the $m R N A$ expression levels of BNP and $\beta-M H C$. As BNP and $\beta$-MHC are markers of cardiomyocyte hypertrophy, the effects of resistin treatment on the expression of BNP and $\beta$-MHC mRNA was investigated in $\mathrm{H} 9 \mathrm{c} 2$ cells. The results demonstrate that resistin treatment increased the expression of BNP and $\beta$-MHC mRNA. Additionally, the results identified that metformin treatment suppressed resistin-induced increase of BNP and $\beta$-MHC mRNA expression (Fig. 3).

Resistin treatment reduces the phosphorylation of $L K B 1$ and $A M P K$. To further investigate the underlying molecular mechanism by which resistin induces cardiac hypertrophy, we used western blot analysis to evaluate the phosphorylation status of LKB1 and AMPK following resistin treatment. Treatment of resistin decreased phosphorylation of LKB1 and AMPK, whereas total LKB1 and AMPK protein expression was unchanged. Since metformin is an activator of LKB1 and AMPK $(16,17)$, treatment of metformin increased expression of phosphorylated LKB1 and AMPK that was decreased by resistin (Fig. 4).

\section{Discussion}

Increasing evidence indicates that resistin induces cardiac hypertrophy. However, the underlying mechanisms by which resistin induces cardiac hypertrophy remain largely unknown. In the present study, resistin treatment increased cell size, protein synthesis and hypertrophic marker BNP and $\beta$-MHC mRNA expression, suggesting that resistin can induce cardiomyocyte hypertrophy. Resistin-induced cardiac hypertrophy may be mediated by LKB1/AMPK pathway.

Resistin is an adipocyte-secreted cytokine, released from fat cells in rodents (10). However, in humans, resistin is secreted from monocytes and macrophages (18-21). The function of resistin is related to obesity, diabetes and insulin resistance (10). Furthermore, treatment of resistin impairs glucose tolerance and insulin action, whereas loss of resistin function improves insulin resistance (22-24). Overexpression of resistin induces cardiac hypertrophy in neonatal rat cardiomyocytes through the activation of the oxidative stress (25), IRS1/MAPK (11), AMPK/mTOR/ p70S6K and Apoptosis signal-regulating kinase 1 (ASK1)/ JNK/IRS1 signaling pathways (13).

Liver kinase 1 is a tumor suppressor gene widely expressed in all tissues, and is involved in cell polarity, cell motility, protein translation, energy metabolism and various signal transduction pathways (26-29). LKB1 can phosphorylate downstream AMPK at threonine 172 (30-32). Metformin, phenformin and AICAR are activators of AMPK (4,33-35). The activation of AMPK has antiproliferative activity. The mTOR pathway is one of the downstream targets of AMPK, which is negatively regulated by LKB1/AMPK signaling. Inhibition of mTOR activity leads to inhibition of protein synthesis and proliferation (36). Furthermore, the LKB1-AMPK pathway plays an important role in cardiac hypertrophy development. It has been shown previously that 4-hydroxy-trans-2-nonenal (HNE) and miR-451 promote cardiac hypertrophy through suppression of the LKB1/AMPK pathway $(37,38)$. By contrast, resveratrol or NAD prevents cardiac hypertrophy through enhancing the LKB1/AMPK signal transduction pathway $(31,39,40)$. The current study demonstrates that resistin decreases phosphorylation of LKB1, and subsequently decreases phosphorylation of AMPK. Whereas metformin, an activator of LKB 1 and AMPK, increased phosphorylation of LKB1 that is decreased by resistin. Similarly, metformin increased expression of phosphorylated AMPK, is suppressed by resistin. These results suggest that resistin promotes cardiomyocyte hypertrophy via the LKB1/AMPK pathway.

In conclusion, resistin treatment elevates BNP and $\beta$-MHC mRNA expression, cell surface area and protein synthesis, and decreases the levels of LKB1 and AMPK phosphorylation, suggesting that resistin induces cardiac hypertrophy through inactivation of LKB1/AMPK signaling pathway. These results suggest that prevention of resistin may be useful in the treatment of cardiac hypertrophy.

\section{References}

1. Frey N, Katus HA, Olson EN and Hill JA: Hypertrophy of the heart: A new therapeutic target? Circulation 109: 1580-1589, 2004.

2. Carreño JE, Apablaza F, Ocaranza MP and Jalil JE: Cardiac hypertrophy: Molecular and cellular events. Rev Esp Cardiol 59: 473-486, 2006 (In Spanish).

3. Alessi DR, Sakamoto K and Bayascas JR: LKB1-dependent signaling pathways. Annu Rev Biochem 75: 137-163, 2006.

4. Shaw RJ, Kosmatka M, Bardeesy N, Hurley RL, Witters LA, DePinho RA and Cantley LC: The tumor suppressor LKB1 kinase directly activates AMP-activated kinase and regulates apoptosis in response to energy stress. Proc Natl Acad Sci USA 101: 3329-3335, 2004.

5. Hawley SA, Boudeau J, Reid JL, Mustard KJ, Udd L, Mäkelä TP, Alessi DR and Hardie DG: Complexes between the LKB1 tumor suppressor, STRAD alpha/beta and MO25 alpha/beta are upstream kinases in the AMP-activated protein kinase cascade. J Biol 2: 28, 2003.

6. Baas AF, Boudeau J, Sapkota GP, Smit L, Medema R, Morrice NA, Alessi DR and Clevers HC: Activation of the tumour suppressor kinase LKB1 by the STE20-like pseudokinase STRAD. EMBO J 22: 3062-3072, 2003.

7. Stapleton D, Mitchelhill KI, Gao G, Widmer J, Michell BJ, Teh T, House CM, Fernandez CS, Cox T, Witters LA and Kemp BE: Mammalian AMP-activated protein kinase subfamily. J Biol Chem 271: 611-614, 1996.

8. Alexander A and Walker CL: The role of LKB1 and AMPK in cellular responses to stress and damage. FEBS Lett 585: 952-957, 2011.

9. Zaha VG and Young LH: AMP-activated protein kinase regulation and biological actions in the heart. Circ Res 111: 800-814, 2012.

10. Steppan CM, Bailey ST, Bhat S, Brown EJ, Banerjee RR, Wright CM, Patel HR, Ahima RS and Lazar MA: The hormone resistin links obesity to diabetes. Nature 409: 307-312, 2001.

11. Kim M, Oh JK, Sakata S, Liang I, Park W, Hajjar RJ and Lebeche D: Role of resistin in cardiac contractility and hypertrophy. J Mol Cell Cardiol 45: 270-280, 2008.

12. Graveleau C, Zaha VG, Mohajer A, Banerjee RR, Dudley-Rucker N, Steppan CM, Rajala MW, Scherer PE, Ahima RS, Lazar MA and Abel ED: Mouse and human resistins impair glucose transport in primary mouse cardiomyocytes and oligomerization is required for this biological action. $\mathrm{J}$ Biol Chem 280: 31679-31685, 2005. 
13. Kang S, Chemaly ER, Hajjar RJ and Lebeche D: Resistin promotes cardiac hypertrophy via the AMP-activated protein kinase/mammalian target of rapamycin (AMPK/mTOR) and c-Jun N-terminal kinase/insulin receptor substrate 1 (JNK/IRS1) pathways. J Biol Chem 286: 18465-18473, 2011.

14. Sun B, Huo R, Sheng Y, Li Y, Xie X, Chen C, Liu HB, Li N, $\mathrm{Li}$ CB, Guo WT, et al: Bone morphogenetic protein-4 mediates cardiac hypertrophy, apoptosis and fibrosis in experimentally pathological cardiac hypertrophy. Hypertension 61: 352-360, 2013.

15. Merten KE, Jiang $\mathrm{Y}$ and Kang YJ: Zinc inhibits doxorubicin-activated calcineurin signal transduction pathway in H9c2 embryonic rat cardiac cells. Exp Biol Med (Maywood) 232: 682-689, 2007.

16. Shaw RJ, Lamia KA, Vasquez D, Koo SH, Bardeesy N, Depinho RA, Montminy M and Cantley LC: The kinase LKB1 mediates glucose homeostasis in liver and therapeutic effects of metformin. Science 310: 1642-1646, 2005.

17. Zhou G, Myers R, Li Y, Chen Y, Shen X, Fenyk-Melody J, Wu M, Ventre J, Doebber T, Fujii N, et al: Role of AMP-activated protein kinase in mechanism of metformin action. J Clin Invest 108 1167-1174, 2001

18. Patel L, Buckels AC, Kinghorn IJ, Murdock PR, Holbrook JD, Plumpton C, Macphee $\mathrm{CH}$ and Smith SA: Resistin is expressed in human macrophages and directly regulated by PPAR gamma activators. Biochem Biophys Res Commun 300: 472-476, 2003.

19. Lu SC, Shieh WY, Chen CY, Hsu SC and Chen HL: Lipopolysaccharide increases resistin gene expression in vivo and in vitro. FEBS Lett 530: 158-162, 2002

20. Kaser S, Kaser A, Sandhofer A, Ebenbichler CF, Tilg H and Patsch JR: Resistin messenger-RNA expression is increased by proinflammatory cytokines in vitro. Biochem Biophys Res Commun 309: 286-290, 2003.

21. Lehrke M, Reilly MP, Millington SC, Iqbal N, Rader DJ and Lazar MA: An inflammatory cascade leading to hyperresistinemia in humans. PLoS Med 1: e45, 2004.

22. Banerjee RR, Rangwala SM, Shapiro JS, Rich AS, Rhoades B, Qi Y, Wang J, Rajala MW, Pocai A, Scherer PE, et al: Regulation of fasted blood glucose by resistin. Science 303: 1195-1198, 2004.

23. Muse ED, Obici S, Bhanot S, Monia BP, McKay RA, Rajala MW, Scherer PE and Rossetti L: Role of resistin in diet-induced hepatic insulin resistance. J Clin Invest 114: 232-239, 2004.

24. Rajala MW, Obici S, Scherer PE and Rossetti L: Adipose-derived resistin and gut-derived resistin-like molecule-beta selectively impair insulin action on glucose production. J Clin Invest 111: 225-230, 2003.

25. Chemaly ER, Hadri L, Zhang S, Kim M, Kohlbrenner E, Sheng J, Liang L, Chen J, K-Raman P, Hajjar RJ and Lebeche D: Long-term in vivo resistin overexpression induces myocardial dysfunction and remodeling in rats. J Mol Cell Cardiol 51: 144-155, 2011

26. Sanchez-Cespedes M, Parrella P, Esteller M, Nomoto S, Trink B, Engles JM, Westra WH, Herman JG and Sidransky D: Inactivation of LKB1/STK11 is a common event in adenocarcinomas of the lung. Cancer Res 62: 3659-3662, 2002.

27. Guldberg P, thor Straten P, Ahrenkiel V, Seremet T, Kirkin AF and Zeuthen J: Somatic mutation of the Peutz-Jeghers syndrome gene, LKB1/STK11, in malignant melanoma. Oncogene 18 : 1777-1780, 1999

28. McCabe MT, Powell DR, Zhou W and Vertino PM: Homozygous deletion of the STK11/LKB1 locus and the generation of novel fusion transcripts in cervical cancer cells. Cancer Genet Cytogenet 197: 130-141, 2010.
29. Zheng B, Jeong JH, Asara JM, Yuan YY, Granter SR, Chin L and Cantley LC: Oncogenic B-RAF negatively regulates the tumor suppressor LKB1 to promote melanoma cell proliferation. Mol Cell 33: 237-247, 2009.

30. Oakhill JS, Chen ZP, Scott JW, Steel R, Castelli LA, Ling N, Macaulay SL and Kemp BE: $\beta$-Subunit myristoylation is the gatekeeper for initiating metabolic stress sensing by AMP-activated protein kinase (AMPK). Proc Natl Acad Sci USA 107: 19237-19241, 2010

31. Dolinsky VW, Chan AY, Robillard Frayne I, Light PE, Des Rosiers C and Dyck JR: Resveratrol prevents the prohypertrophic effects of oxidative stress on LKB1. Circulation 119: 1643-1652, 2009

32. Calamaras TD, Lee C, Lan F, Ido Y, Siwik DA and Colucci WS: Post-translational modification of serine/threonine kinase LKB1 via adduction of the reactive lipid species 4-Hydroxy-trans-2-nonenal (HNE) at lysine residue 97 directly inhibits kinase activity. J Biol Chem 287: 42400-42406, 2012.

33. El-Mir MY, Nogueira V, Fontaine E, Avéret N, Rigoulet M and Leverve X: Dimethylbiguanide inhibits cell respiration via an indirect effect targeted on the respiratory chain complex I. J Biol Chem 275: 223-228, 2000.

34. Owen MR, Doran E and Halestrap AP: Evidence that metformin exerts its anti-diabetic effects through inhibition of complex 1 of the mitochondrial respiratory chain. Biochem J 348: 607-614, 2000.

35. Shackelford DB, Abt E, Gerken L, Vasquez DS, Seki A, Leblanc M, Wei L, Fishbein MC, Czernin J, Mischel PS and Shaw RJ: LKB1 inactivation dictates therapeutic response of non-small cell lung cancer to the metabolism drug phenformin. Cancer Cell 23: 143-158, 2013.

36. Zhou W, Marcus AI and Vertino PM: Dysregulation of mTOR activity through LKB1 inactivation. Chin J Cancer 32: 427-433, 2013.

37. Calamaras TD, Lee C, Lan F, Ido Y, Siwik DA and Colucci WS: The lipid peroxidation product 4-hydroxy-trans-2-nonenal causes protein synthesis in cardiac myocytes via activated mTORC1-p70S6K-RPS6 signaling. Free Radic Biol Med 82: 137-146, 2015.

38. Kuwabara Y, Horie $\mathrm{T}$, Baba $\mathrm{O}$, Watanabe S, Nishiga M, Usami S, Izuhara M, Nakao T, Nishino T, Otsu K, et al: MicroRNA-451 exacerbates lipotoxicity in cardiac myocytes and high-fat diet-induced cardiac hypertrophy in mice through suppression of the LKB1/AMPK pathway. Circ Res 116: 279-288, 2015.

39. Dolinsky VW, Chakrabarti S, Pereira TJ, Oka T, Levasseur J, BekerD,Zordoky BN,MortonJS,NagendranJ,LopaschukGD, etal: Resveratrol prevents hypertension and cardiac hypertrophy in hypertensive rats and mice. Biochim Biophys Acta 1832: 1723-1733, 2013

40. Pillai VB, Sundaresan NR, Kim G, Gupta M, Rajamohan SB, Pillai JB, Samant S, Ravindra PV, Isbatan A and Gupta MP: Exogenous NAD blocks cardiac hypertrophic response via activation of the SIRT3-LKB1-AMP-activated kinase pathway. J Biol Chem 285: 3133-3144, 2010 